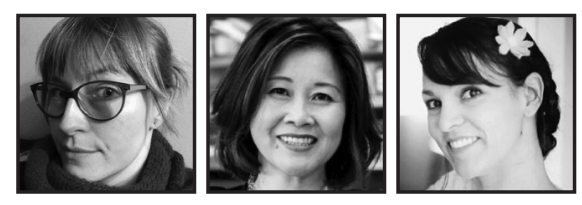

\title{
Constructing Pre-Service Teacher Identities Through Processes of Parallax
}

\author{
R. Varainja Stock, Pauline Sameshima, and Dayna Slingerland, \\ Lakehead University
}

\section{ABSTRACT}

This paper presents an arts-integrated process for teacher educators to engage their students in critical thinking, meaning-making, and knowledge construction in order to enable pre-service teachers to analyze metanarratives that inform their teacher identities. The research team used the Parallaxic Praxis research model to frame its art-making investigations in a practice-based research process. The three researchers each created an artefact as part of their individual inquiry of the data set, comprising 90 material cloaks created by pre-service teachers, to enter into dialogue addressing the prevailing metanarratives expressed by the pre-service teacher participants.

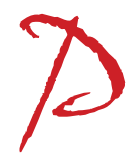

re-service teacher (PST) self-identity, which underpins and drives the construction of teaching philosophies and practice, is arguably one of the most essential components for PSTs to investigate in their teacher preparation programs. High numbers of new teachers continue to leave the teaching profession in Canada (Clandinin et al., 2012; Clark \& Antonelli, 2009; Gambhir, Broad, Evans, \& Gaskell, 2008), echoing ongoing concern with attrition rates in the United States (Barnes, Crowe, \& Schaefer, 2007; Boe, Cook, \& Sunderland, 2008; Liu \& Ramsay, 2008; NCES, 2011). Many teachers who leave the profession in the early years do so partially because their teacher education programs lack "systematic efforts to provide pre-service teachers with a realistic understanding of teachers' emotional experiences and developmental stages" (Hong, 2010, p. 1540). We "acknowledge that the teacheridentity is continually shaping and morphing with experience" (Sameshima, 2007b, p. 6); however, in practice, some teachers remain locked in preconceived idealistic notions 
of the K-12 environment (Cheng, Chan, Tang, \& Cheng, 2009) that are unchallenged until these PSTs enter the profession. This research seeks to better understand PSTs' conceptions of their teacher identities and to offer teacher educators a process for enabling thought-provoking, critical, and dialogic discussions on teacher identity development in their programs.

This paper presents an arts-engaged process for teacher educators to move beyond reflection-writing assignments and discussion methods with their students to processes of critical thinking, meaning-making, and knowledge construction in order to enable PSTs to relook at the metanarratives that inform the development of their personal teacher identities. Understanding personal narratives, often built on established metanarratives, can enable PSTs to construct more meaningful professional identities and, in turn, reduce teacher attrition (see Izadinia, 2013, pp. 695-696). This paper presents the first phase of analysis from one of three sites involved in a multi-site research project spanning three Canadian universities.

The research team of three artist-researchers used the Parallaxic Praxis research model (Sameshima \& Vandermause, 2008) to frame their art-making investigations in a practice-based research process. The three researchers each created an artefact as part of their individual inquiry of the data set, comprising 90 material cloaks (see Figure 1) created by pre-service teachers. Similarly, White and Lemieux (2015), co-researchers at one of the other project sites, use the creation of artefacts, in their case "identity-boxes," to examine pre-service teacher identity and the teaching self.

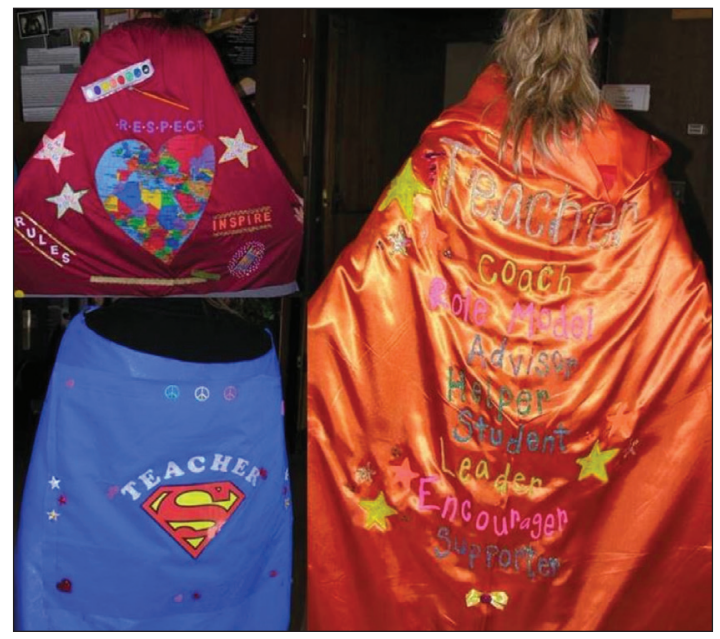

Fig. 1: Clockwise from top left: Cloaks by "Grace", "Chloe," and "Olivia" 
The Parallaxic Praxis model involves the translation of data into artistic mediums that are used by the research team to provoke collaborative engagement, knowledge production, and further questionings. These artefacts are also used to generate discussions with participants and broader audiences. The range of modal translations can include numeric data presented in the form of a graph; or interview transcripts rendered through translations of poetry and photographs (Sameshima, Vandermause, Chalmers, \& Gabriel, 2009); or music, graphic experiments, and watercolour paintings (Maarhuis, Sameshima, \& Chalykoff, 2014).

As a collaborative research model, parallaxic praxis encourages critical thinking in order to "understand core, underlying truths, not simply that superficial truth that may be most obviously visible" (hooks, 2010, p. 9). These translative practices resulting in artefacts can offer concrete means to better challenge and understand how preconceived, clichéd notions of teacher identity affect pre-service teachers' ongoing professional identity formation. We provide a process, called Ekphrastic Catechization, for engaging pre-service teachers in dialogue to move beyond the constructed clichés.

\section{PST Teacher Identity Development}

Much research has been done which reveals a naiveté in PSTs' expectations for their future roles. The use of reflection, art, and metaphor have consistently revealed a disconnect between what PSTs envision their future roles to be and what their future roles will actually be. This disconnect may be setting PSTs up for unnecessary negative experiences early in their careers due to unrealistic expectations. The 90 PST participants in this study consistently presented idealistic images on their cloaks and in their reflection writings of their future roles as teachers. The data in our study revealed a variety of utopian narratives focused on establishing classroom families and communities; being beholders of inspiration and encouragement to their students; and caring for each student as an individual. While these goals are wholesome, prior research purports that unrealistic expectations by new teachers may negatively affect their decision to stay in the profession (Barnes et al., 2007; Hong, 2010; Liu \& Ramsey, 2008; Schafer, 2013); how they teach; and how successful they become as teachers (Carlyle \& Woods, 2002; Cheng et al., 2009; Head, 1992; Hong, 2010).

Developing a professional identity is an ongoing process as identities are constantly navigated through interactions, in context, and over time (Gee, 2000, see p. 99). Geijsel and Meijers (2005) contend that teacher identity formation is informed by 
"interpretations [emphasis in original] of concepts as they exist in the culturally constructed worlds in which the person participates" (p. 425). Further, identity formation involves an emotional element as meanings are developed through relationship with culture and events. "Identity construction is seen to be a circular learning process, in which experiences and self-concept are related through using concepts and endowing them with personal sense" (p. 425). To further explain this connection, Geijsel and Meijers found that "concepts and meanings that are available ... but cannot be related to experiences and thus are not given a personal sense, will not become a part of the identity configuration" (p. 425). Thus, although many teacher education programs may already include identity development programming, unless teacher educators are able to encourage PSTs' personal connections to teaching philosophies, little change will occur.

Previous research has identified links between teacher identity and attrition (Hong, 2010) and a lack of a connection between PST teacher identity and the actual demands of the profession (Beltman, Glass, Dinham, Chalk, \& Nguyen, 2015; Buchanan, 2015; Geisel \& Meijers, 2005; Hong, 2010; Thomas \& Beauchamp, 2011). Hong's (2010) US study involving 84 teacher and PST participants identified a naiveté and idealism associated with PST professional identities. Similarly, a Canadian study that asked PSTs to explain their teacher identity through metaphor, demonstrated a marked difference between the metaphors used by PSTs and those used after participants had begun teaching (Thomas \& Beauchamp, 2011). The metaphors employed by PSTs "focused on supporting future students, nurturing, protecting and helping them find their way" (p. 765) whereas the metaphors used after entering the teaching profession focused heavily on personal survival and meeting the challenges in the classroom. Building on previous research (Eren \& Tekinarslan, 2013; Northcote \& Featherstone, 2006; Pinnegar, Mangelson, Reed, \& Groves, 2011; Thomas \& Beauchamp, 2011), Buchanan (2015) explored the use of metaphors to further understand the shift in identities from PSTs to practising teachers and how this shift affects the profession and teacher attrition. The metaphors in Buchanan's study were consistent with previous studies of PSTs as the majority of PST participants created metaphors that were "positive and optimistic" (p. 44). Buchanan also found that PSTs presented "inflated views of the control a teacher exercises" (p. 44) demonstrating a naïve or uninformed vision of themselves as future teachers. This idyllic outlook is problematic as it increases the likelihood they will "be confronted with the reality of little control and, at times, even hostility and resistance from a source they might not suspect" (p. 44).

Studies of PSTs' identity development have foregrounded the use of activities that involve reflection "as a way of questioning taken-for-granted assumptions and 
teaching practices stabilized in early stages of a teacher's career" (Izadinia, 2013, p. 697). Art-making and reflection have been used as effective processes for self-exploration in teacher identity development (Boulton-Funke, 2014; Sinner, Wicks, \& Rak, 2015; Weber \& Mitchell, 1996; White \& Lemieux, 2015). Beltman and collaborators (2015) studied 125 pre-service teachers at a university in Australia. Participants were asked to draw a picture based on the question: What kind of teacher do you hope to become? The drawings overwhelmingly presented positive expectations for their future identities as teachers. The PSTs' "drawings indicated a confidence in their capacity to become the teacher and to do the work of teaching in an engaging and caring manner. Much of what is relevant to teaching, however, was not addressed" (p. 238). A Canadian study in Quebec with 64 university students enrolled in undergraduate and graduate programs in education explored their professional identities through drawing and written reflection (Weber \& Mitchell, 1996). Students were instructed to draw an image of a teacher and write a reflection based on their drawings, which they then presented to their classmates. "In reflecting and commenting on the pictures, they became aware of the incredible power that past experience and stereotypes seemed to have on them." (p. 307). The researchers affirmed that this process provided space for students to "articulate previously unexamined ambivalences and tensions around their identity and work as teachers" (p. 306).

\section{Methodology}

\section{Parallaxic Praxis Research Model}

The Parallaxic Praxis model (see Figure 2) was developed by an interdisciplinary research team (Sameshima \& Vandermause, 2008) and has since been used in various ways to provoke dialogic discussions on a diverse range of topics including interpersonal violence (Maarhuis \& Sameshima, 2013); assistive technology (Marino, Sameshima, \& Beecher, 2009); teacher education (Sameshima, 2009), Aboriginal mental health care (Saunders, 2015), and empowering older persons (Neumiller, Corbett, Gates, \& Vandermause, 2015).

Parallaxic Praxis is a research model for conducting collaborative arts-integrated research that furthers understanding and provokes new questions, never settling on a conclusion, rather opening up the dialogue for unbounded, spiralling inquiry (Saunders, 2015). 
The concept of parallax comes from astronomy and "is the apparent change of location of an object against a background due to a change in observer position or perspective shift" (Sameshima, 2007a, p. 293). As a collaborative method, parallax helps to understand how an object will look different depending on the vantage point or line of sight of the viewer. In effect, different people will see different things based upon where they stand, and therefore, researchers from different fields will interpret the same data differently, not only through the words they use, but also through the discourse of their fields, and varying funds of knowledge. Additionally, using artistic renderings, or modal translations (text to art, numbers to graphs, etc.), creates energetic space for multiple interpretations, which "affords the audience to think more critically about the content from a personal meaning-making perspective" (Sameshima et al., 2009, p. 10). These functional artefacts, in that they are artworks imbued with meaning or created for the sake of generating meaning, can be created in any artistic mediumincluding narratives or stories, performance, poetry, and visual arts - and are intended to be used to provoke dialogue. Eisner (2008) explained that "something that mediates the researchers' observations and culminates in a form that provides the analogous structure" (p. 7) can be the avenue to articulating the unsaid.

In the process of creation, questions will arise which begin an inertial movement toward knowledge generation. As well, in bringing together the artist-researchers' created artefacts, not only can the juxtaposition of artefacts offer provocative spaces of exchange between mode and meaning, and challenge normativity inherent in social constructs, but also "systems of analysis and interactions in the hybrid nexus spaces can be discussed" (Sameshima et al., 2009, p. 10). 


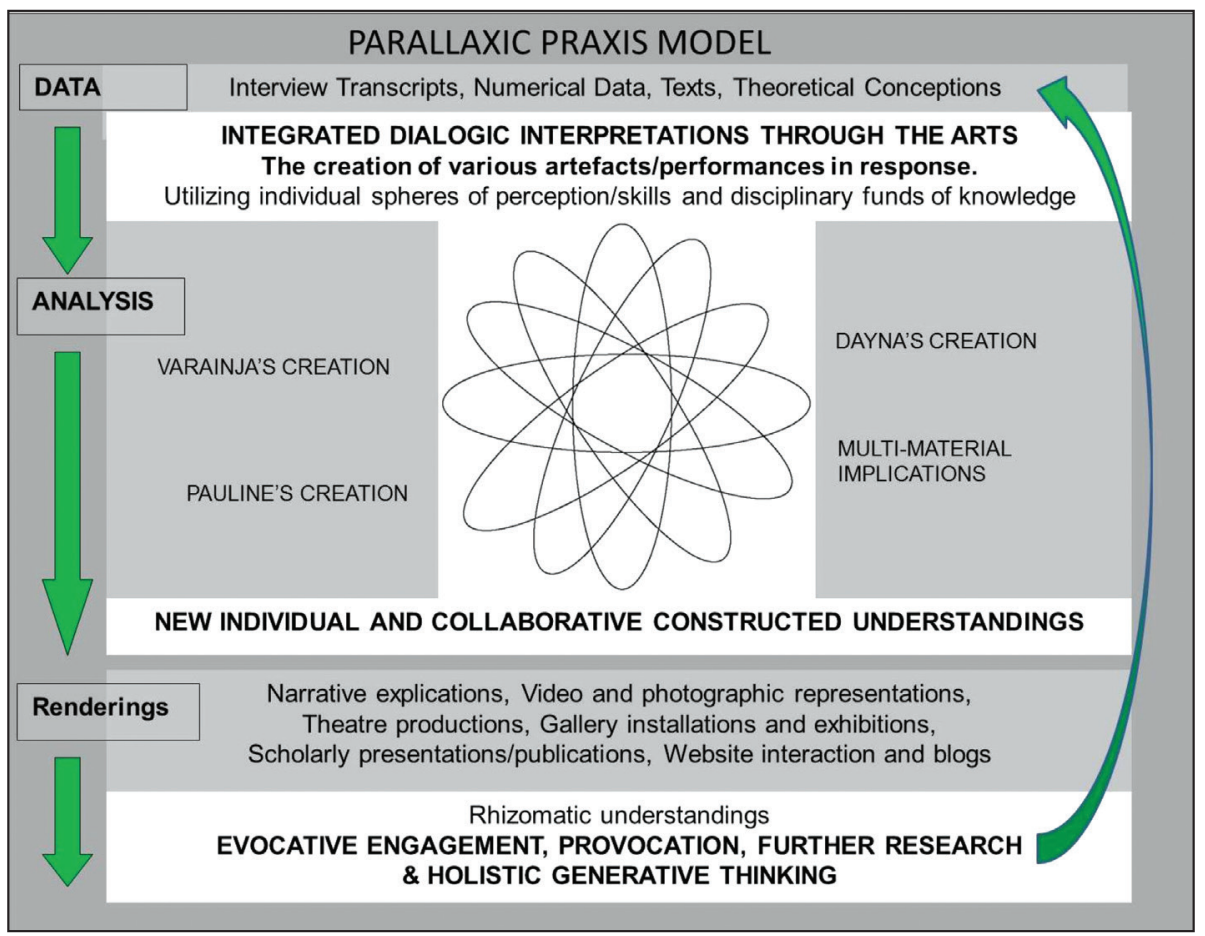

Fig. 2: Parallaxic praxis framework

\section{Ekphrastic Catechizations}

Parallaxic praxis research uses ekphrastic catechizations, or questioning within specific themes, to guide analytic processes of the data visualizations. "Ekphrasis is a rhetorical device where one medium tries to re-create an object's essence and form in another medium in the hopes of relating more directly with the audience." (Maarhuis, Sameshima, \& Chalykoff, 2014, np). To catechize is to question systematically. In this framework, catechizations are used to direct conversations when looking at collections of artefacts in order to move the dialogue forward and to further inspire questions from investigators and audiences. For example, instead of only describing "what" each artefact is, the seven catechization categories interrogate how the artefacts work together and what they do as artefacts of analysis. The ekphrastic catechizations are mimesis, poiesis, palimpsest, intertextuality, antiphona, sorites, and aporia. Importantly, the catechizations offer a means for researchers to theorize and discuss the artefacts constructed from the original data.

Mimesis "is the relational, ecstatic re-presentation" of a previous work. In this model, mimesis is the act of translating data in order to relate it to a larger audience. 
"Mimetic works are not static copies or an imitation but rather ecstatic formations that unfold ontologically, fluidly, temporally, and referentially" (Maarhuis et al., 2014, $\mathrm{np})$. In the context of this research, the research team created mimetic art works to reveal the participant metanarratives to audiences. The researcher-generated artefacts are "active and dialectical" (Lotz, 2012, p. 93) and contribute to clarification of ideas. A possible question in this category in relation to the artefacts could be: How have we rendered similar metanarratives in our three artefacts?

Poiesis is an event in parallaxic praxis research when the mimetic work comes to life through interpretation, dialogue, bearing witness, or reflection. The mimetic work provides the opportunity for an interaction, an event, for the researcher(s), participants, and audiences to respond to the work of art as it is "recreated every time it is aesthetically experienced" (Dewey, 1934/2005, p. 113). A question used here may be: What similarities and differences do we notice today between the three artworks?

A palimpsest is used to describe something that has been reused or altered but still bears visible traces of its earlier form. In parallaxic praxis the mimetic work is already a palimpsest, presenting new ideas built on older ones in a new form. The artefact is the dialogic in physical form, reaching back and reciprocally changing meaning of the data and the artefact through the interchange of creation and construction (see Bakhtin, 1981). The PSTs' cloaks and reflection writings are the original texts that form the basis for the research team's mimetic works to create new understandings and provide opportunity for poiesis. Palimpsest provides the depth and layers to allow both the participant and the researcher to be present at once. Ensuring the participant perspectives are present is "critical in an arts-based text" (Barone \& Eisner, 2012, p. 134). The relationship between the multiple layers creates an ongoing dialogue where the artworks are viewed by different audiences, in different contexts, and at different times. The questions used here could be: What inspired you to use that particular material? In what way does your artefact echo or trace the data?

Intertextuality adds breadth to interpretations by creating a relationship between the various texts - the mimetic works and participant data-and meaning is derived from seeing or unpacking the researcher-generated artworks in reference to each other and in reference to the participant-generated artwork. The question here could be: How do the three artefacts work in combination to teach us something anew?

Antiphona expands on the concept of intertextuality in parallaxic praxis. Antiphona is a harmony, "a versicle or sentence sung by one choir in response to another" (Oxford English Dictionary, 2016). Each researcher created a separate response 
to the participant-generated artworks and writings. Once these pieces were created, we brought them together to create dialogue between the pieces and the meaning infused in them individually and as a collective. The choral response allows for a fuller resounding response to our inquiry question. Here, a question could be: In what ways do the materials we used and the responses we made echo one another?

Sorites refers to the collaborative process of analysis in parallaxic praxis research. The combination of researcher, participant, and audience interpretation

is an act of cumulation or a heaping of pertinent phenomenal elements, language, and interpretations before one crosses a decision line or threshold that may be indistinct but, in the final analysis, is recognized as a process that answers research questions. (Maarhuis et al., 2014, np)

The practice of sorites in research interpretation is therefore contextually bound and "requires acceptance by and interaction with the audience as well as participants and the community of those who have a stake in the particular cultural phenomena" (np). A question we might ask here is: What specific quotes pushed us to integrate the phenomenon into our final rendering?

Aporia means "an impasse or puzzlement" and philosophically is a "puzzle or a seemingly insoluble impasse in an inquiry, often arising as a result of equally plausible yet inconsistent premises. ... the state of being perplexed or at a loss" (Collins English Dictionary, 2011). "To embrace aporia, the researcher, viewer, and participant must sit in the dissonance of simultaneous and seemingly contradictory life circumstances that do not fit into familiar cultural narratives and 'truths' (Dewey, 1934/2005; Spivak, 2013)." (Maarhuis et al., 2014, np). Our question here could be: How do the artefacts play with or against one another?

By using the catechizations to guide discussion, researchers can intentionally attempt to approach the artefacts from original, revelatory, and more critical perspectives.

\section{Method}

Members of the research team each created an artefact to re-present the combined essence of 90 PSTs' material cloaks. All the researchers familiarized themselves with the previously collected PST data (material cloaks and written reflection pieces) in ATLAS ti, 
a qualitative analysis program. The researchers also worked together in analyzing the data and discussed prevailing themes, connections, and issues that stood out in the PST data. Concurrently, the researchers worked independently on creating their artefact. With the belief that "it is through the making, both in the midst of construction and in reflection, that new understandings and knowledge are acknowledged" (Sameshima, 2007b, p. 5), the researcher-generated artefacts then became points of dialogue for analyzing PST identity development.

\section{Participants}

This analysis draws on previously collected data from 90 PSTs from a teacher education program at a university in the United States. Student composition in the teacher education program was predominantly female and the participant sample reflected this. PSTs were recruited from three sections of a mandatory course called K-8 Arts Integration. Participants voluntarily provided written consent for their course assignment to be used as research. University ethics approval was granted to carry out this project at the data collection site, as well as the current researchers' university, and all ethical protocols were followed in the use, processing, and dissemination of findings in this study.

\section{Data}

As part of their course, students were instructed to create a material representation of their developing teacher identity in the form of a cloak that was then presented to their respective classes. Students used a myriad of materials including photographs of family and friends, patterned prints, iron-on transfers, paints, and markers (see Figure 1). To accompany their cloaks and their presentations, the students were required to write a reflection paper describing their process and learning. The cloaks were photographed, capturing as much detail as possible, and then digitized. The reflection writings were submitted electronically. To process the data, participants were assigned pseudonyms. All images and reflection writings were de-identified before being entered into ATLAS.ti.

\section{Researcher-Created Artefacts}

The following section shares individual reflections on the three artist-researchercreated artefacts. 


\section{Tranquility by Dayna Slingerland}

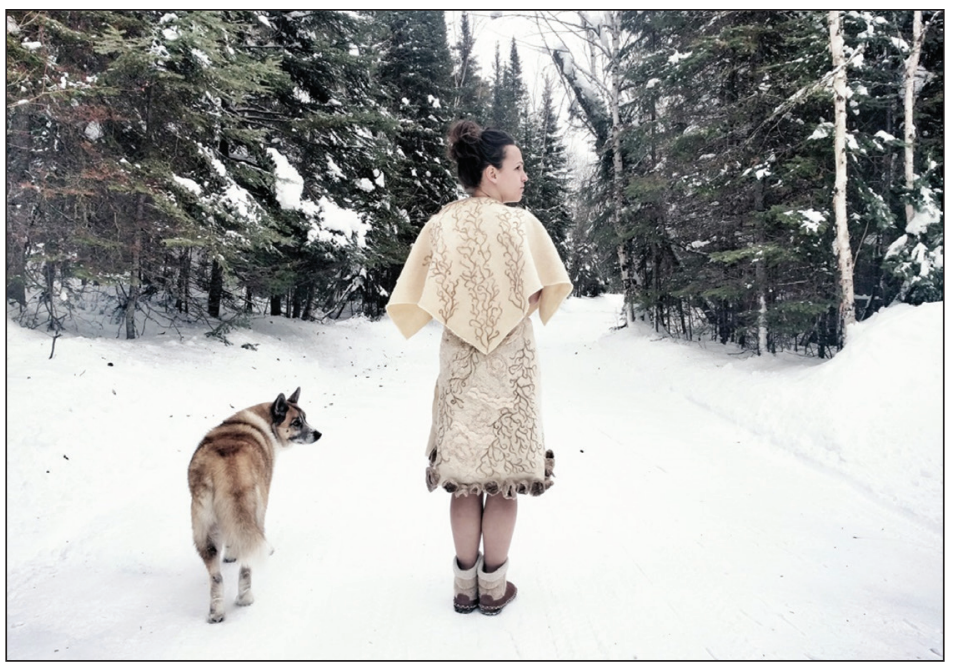

Fig 3: Artist and model: Dayna Slingerland (2016). Tranquility. Wool needle felting and wet felting

The material and aesthetic composition of my piece was inspired by the encouraging air within the PSTs' writing. I wanted to create a piece that would be pleasing to wear by using a wool blanket and merino fleece for a feeling, soft to the touch as well as warm to the body. This piece covers and comforts as do the PSTs' idealistic visions for student learning. One participant described, "It is essential that my classroom be a warm and inviting place, one that both my students and myself feel comfortable in so that in turn, we will all be able to work better" (Alexa). Another participant explained, "I truly value each student's uniqueness, and that I would hope that they can respect one another for their differences so my classroom will be a warm, positive, nonjudgmental place for them to learn and grow" (Laura).

While working on the finer details of the cloak, I integrated materials and patterns to reflect a deeper complexity. The felted spiralling and climbing lines that cover the piece remain separated and broken apart from one another. I felted on lace and yarn that twisted and tangled together. I wondered while reading the teacher identity reflections if the students had given consideration to the complexities of personal identities as well as teaching identities. Student teaching identities are based on knowledge of teaching rather than direct experience. Because students "have outsider as opposed to insider knowledge, they expect to teach as they were taught and they are largely unprepared for the realities of teaching in today's classroom" (Beattie, 1997, p. 115). I wanted the 
art piece to speak to the comfort and feelings of security in this outsider knowledge. A participant noted:

All of us either want to replicate a teaching style that impacted us so strongly from our past, or improve the classroom experience because of a bad teacher they once had. Either way, all of our past experiences in education have shaped who we are and why we want to become teachers. (Jasmine)

While reading through the PST reflections, I considered the challenges of engaging in self-reflection and how this skill might affect the process of creating an identity. Lauren wrote: "I have never really reflected on my experiences that have shaped my teaching identity. I really enjoyed thinking of past memories that have inspired me to become a teacher." Additionally, another participant described a reflective process, "The part of this experience that I found most valuable was taking the time to process and reflect on what was truly important to me and to my students" (Alicia). In authentic inquiry:

individuals must choose to pursue their own questions and to engage in the issues. For those who do, it is entirely possible for them to come to see and understand themselves in new ways, to liberate themselves from old and binding visions of themselves, and to imagine themselves as professionals who can create emancipatory, transformative settings and experiences for the students they teach. (Beattie, 1997, p. 124)

I wanted my artefact to speak to being comforted in the "known." Difficulties in possessing a critical consciousness in self-reflection may stem from "the fact that many prospective teachers do not clearly understand what constitutes self-reflection, or how to do it. They confuse reflection with describing issues, ideas, and events" (Gay \& Neftali Kirkland, 2003, p. 182). My art piece shows a comforting, safe, warm ideal, yet the fibres tear away at the seams and the complexity is revealed upon closer examination. Each layer in this piece is bound to the one beneath through the needle-felting technique. I question the depth to which PTSs are bound to the ideal representationare the idealisms a protective layer, or are they helping to build foundations for creating an identity that has yet to take on form? 


\section{Entwined Storying by Varainja Stock}

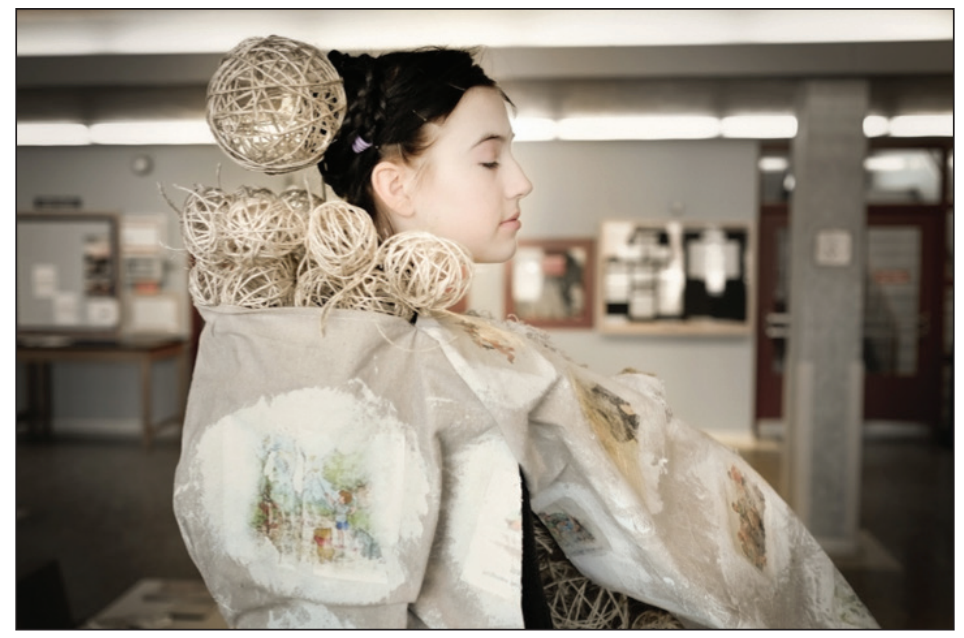

Fig. 4. Artist: Varainja Stock (2016). Entwined storying (Canvas, twine, and mixed media. Model: Mina Stock)

Thomas King (2003) stated: "the truth about stories is that that's all we are" (p. 2). The importance of storying King explained, is that the stories that we tell ourselves, that we are told, and those that make up and construct our lives "can control our lives" (p. 9), "so you have to be careful with the stories you tell. And you have to watch out for the stories that you are told" (p. 10). I was struck by the stories that the PSTs shared about their lives and how these stories had influenced their teacher identities. For some, these identities were embodied in popular cultural icons such as Disney characters and superheroes. One participant wrote:

If you get to know me, you know I love Disney, children's books, and playing games. I am all about being able to have fun and be creative. I put Tinkerbell on my cloak to symbolize this. I am a child at heart. I want my students to know that and know I understand them and have been where they are. I also want to be able to identify with my students and through my ability to see through a child's eyes allows me to do so. (Layla)

Another participant stated, "Disney is a theme that means a lot to me, and I hope that I can incorporate that within my classroom and my cloak I believe helped me show this" (Amari). 
For Entwined Storying I worked with canvas, storybook images, gesso, twine, and white glue. I began with images from The New Basic Readers: The New Friends and Neighbours (1952) (see Figure 5), a collection of stories for teaching reading. I then found second-hand Disney children's books including: Peter Pan, My Very First Winnie the Pooh, Sleeping Beauty, and Snow White and the Seven Dwarfs. I wanted the images from the storybooks to appear faded and worn away, present but not obvious, so that the observer needs to look closely. I used a method of reverse image transfer-first painting a section of the canvas with gesso and then placing the paper image-side-down against the gesso to dry. Once dry, the back of the paper was gently removed by dampening it with a wet paintbrush and rolling the paper off with my finger.

There were two sides to many of the participant cloaks. Some students chose to represent their personal lives on the inside and their professional lives on the outside, while in their reflection writings they acknowledged that the two were separate, yet connected. A participant stated, "I also learned that I cannot separate my family from my teacher identity, but I don't think that I should have to. I want my students to view me as another person, one who makes mistakes, learns every day, and has a family" (Erin). The personal and professional were connected and entangled. I created twine balls that rest against the body, keeping the cloak separate from, but connected to the body in some places, distorting the appearance of the figure underneath as the outward appearance is an imperfect translation of the collection of life experiences and stories that make up the individual.

I wanted my cloak to be rough, stiff in some places, and be reminiscent of fantastical/ otherworldly images. Many of the participants recognized that their teacher identity was an unfinished piece that they would continue to develop throughout their lives, especially in the first few years of teaching. This realization often happened in the process of making their cloaks: "A lot of time doing this cloak is reflection time and my fears of not knowing the curriculum or making a few mistakes, my first few years, seem so contrary to what actually matters in the end" (Lindsay). 
Constructing Pre-Service Teacher Identities Through Processes of Parallax

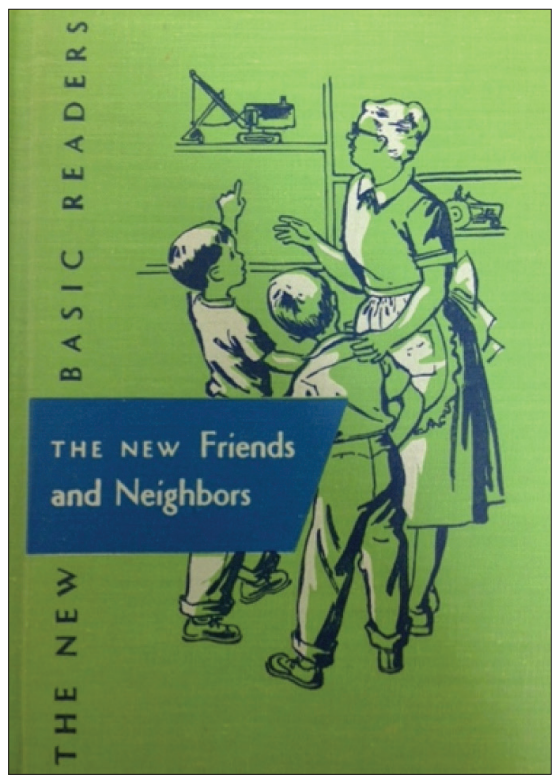

Fig. 5: Scanned cover of The New Basic Readers: The New Friends and Neighbours

\section{The Amway Apple by Pauline Sameshima}

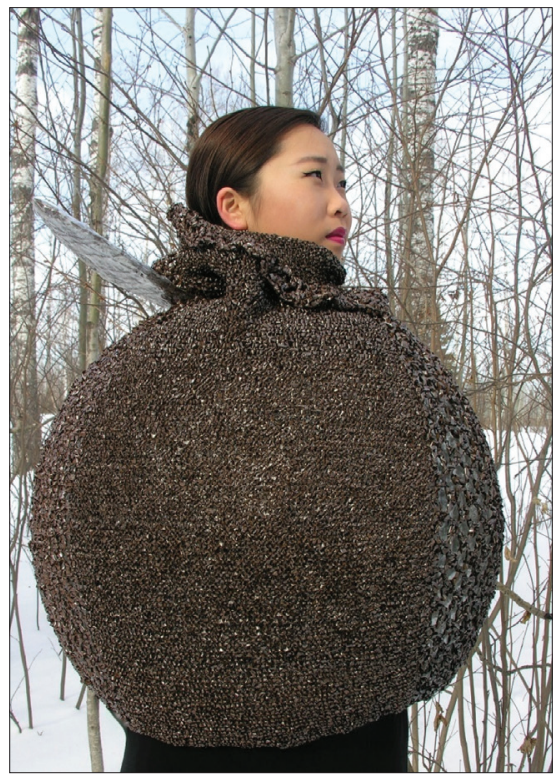

Fig. 6: Artist: Pauline Sameshima (2016). Amway Apple. Cassette tape over a polypropylene film armature. Model: Cameo Sameshima 
I wanted to play with the apple cliché through iconoclastic use of materials. Cassandra sums it up shiningly with "all teachers love apples." Many students referred to the apple as a symbol for teaching, tradition, respect, the future, connection to the love of Mac technology products, love of teaching, and more. Amway Apple was made by knitting and crocheting cassette tape into a covering for an armature in the shape of an apple. The covering is based on a pattern of a cocktail dress. When stretched around the apple and tucked in at the base, the design looks completely transformed. This play with the cocktail dress becoming unrecognizable reflects the disparity between the human form (self) and the expected teacher form (apple). The front has a tightly knitted stitch allowing very little of the armature to be seen. The sides and the back are more exposed. Similarly, the PSTs' constructions of what is public (the face of the identity) received much more energy and consideration than the inside or private side of the cloak.

I chose to use Amway motivational training cassettes from the 1990s specifically for their messages. Amway (American Way) is a direct selling / multi-level marketing company which sells home and personal care products and is the 30th largest private company in America (Forbes, 2015). Many of the training tapes are heartfully told motivational stories - narratives of woe ending in financial freedom. The tapes exemplify the perpetuation of the American dream, Disney character jubilance, and superhero unselfishness that surfaced in the PSTs' visions of their future careers. Amelia noted, "I chose this material because it reflects my excitement and my bright future in my teaching career" and Avery declared, "I want my students to know that I love and support each and every one of them." Rebecca wrote, "I have wanted to be a teacher my whole life and this has greatly impacted my decisions throughout my schooling. This is something that defines who I am as a person." These beautiful narratives of fairy tale-like desire are driven by innocent intentions, goodness, and cultural metanarratives. In a parallel stream, these comments by an Amway sales rep, remind us how these dreams can play out once PSTs start teaching. He says, the Amway tapes "get you in [a] frame of mind that you need to feed on the materials in order to survive." The rep felt that "the barrage of motivation aids put him 'in a performance trap' where he obsessed about achieving, but felt mired in failure" (Morrill \& Stancill, 1995).

The armature (structural form) and leaf are made of polypropylene film packing tape. I intentionally used tape to echo bandaging practices. There are many ways of learning how to teach and most programs include practicum training, or immersion in the field. This "baptism by fire" can be likened to "cut and bandage. " Once assigned a class, teachers are generally completely alone with their students. Whether beneficial or detrimental, numerous layers of bandaging form a solid structure. 
The protective nature of the cliché apple shields the PST but, without armholes, PSTs have little autonomy.

The notions of mothering and care particularly stood out to me. Amanda stated: "I plan on taking care of them and nurturing their growth and learning. If they don't have a loving, safe place to go home to, they will always feel safe and taken care of in school." Amanda wrote about respect and kindness, "something a mother would also teach." Crystal reminisced,

In those small towns everyone cared and loved . . . everyone else. The neighbors looked after neighbors and would bring a casserole or a cake over if someone was sick or needed some help. Someone was always there to care for you and you felt so welcomed. I want my classroom to be a community and I want my students to care for each other as much as I care for them.

These protective notions, and also intentions of care as expressed by many other participants, point to constructions of teacher identity based on the Florence Nightingale Model of teacher as nurse, healer, caregiver, and conduit of curriculum prescriptions (Sameshima, 2007b). An October 11, 2015 blog in theguardian, an online Teacher Network, offers an anonymous student's post aptly titled, "'Show us that you care': A student's view on what makes a perfect teacher." For PSTs and non-PSTs it appears, care is the defining characteristic of good teaching. Aligning and concurring strongly with the 2015 research on PSTs by Beltman and colleagues, the PSTs in our study also focus predominantly on care and love with very limited reflection on specific pedagogical strategies, teaching theories, or the actual performance of teaching. As an elementary classroom teacher for 17 years, I do agree that there are nostalgic familial-like moments re-created in the classroom; however, these moments are integrally embedded within a larger pedagogic sequence which does not appear to be considered by the PSTs.

\section{Discussion}

Resembling the processes of the creation of a text, art production also considers both critical reflection and meanings made by others. According to Sullivan (2005), artistic thinking embodies "an ongoing dialogue between, within, and around the artist, artwork, viewer and context, where each has a role in co-constructing meaning" (p. 9). After working individually on our material cloaks, the research team came together 
to engage in creating a dialogue generated from our artistic renderings (poiesis). This dialogue becomes an accumulation of our individual analyses to bring attention to shared meaning, places of tension, and of divergence in interpretation and experience.

\section{The Disney Phenomena}

All three artefacts highlighted idealized expectations. The PSTs' cloaks and reflection writings enacted powerful entanglements with Disney narratives and the American dream. This participant shares her values:

The front left flap of my cloak has the American flag as its background. This is because I love our country and the freedom each individual has. I believe that the foundation of our government and its structure has influenced how I see life and others. ... My goal is for my students to collaborate with each other and myself as valued pieces to our classroom. I think our founding fathers are wonderful role models of this. They stood up for what they thought, fought for it, and then collaborated together to create a democracy for all people. (Hailey)

While this data was collected at a US university, concerns around attrition rates, disillusionment, and teacher identity offer many commonalities across North American and Australian research. In Canada, we are certainly not immune from Disney, superhero, and American Hollywood tropes.

The "living the dream" trope is illustrated in the nostalgic images from the 1950s reader that Varainja used to create her artefact. We wondered how these tropes affect people's identities, notions of happiness, and expectations about life. In reality, the naïve hopefulness and images of peaceful, safe classroom spaces are in direct opposition to the American dream now fuelled by financialism, greed, and competition (see Haiven \& Khasnabish, 2014; Hess, 2011), resulting in high levels of stress (Pope, Brown, \& Miles, 2015). Challenging PSTs to interrogate metanarratives that drive their self-identities and teaching philosophies will play a critical role in the development of pedagogical practices grounded in current educational contexts.

\section{Becoming}

We noted that the PSTs' teacher identities were informed by their experiences as students, and recollections of "good" teachers from a student perspective. They relied on their experiences as students to inform their professional identities, posing a challenge to teacher educators wishing to help PSTs develop a professional identity. 
Is it possible to create an identity before living that identity? Varainja's cloak offered a path into this discussion. The storybook images on Entwined Storying are "veiled" or blurred through the transfer process, and the twine entanglements are visible yet shrouded by the canvas covering. Pauline's apple armature too, offers a screened view into the PST body. The process of becoming and taking on a new identity is complex. How might PSTs merge who they are, into who they are becoming, when who they are becoming is an unknown? Dayna kept parts of her artefact unembellished, "I was keeping them open as a way of thinking about students absorbing and being susceptible, and thinking of being open to developing an identity that might not totally be their own, and might be one that's been observed."

\section{The Private and the Public}

Participants expressed a tension between their personal and professional identities. For example, one student created a cloak with a double layer; the hidden, inner layer displayed a large cross that was kept from view by another layer of material. Through our discussion it was revealed how each of us had intentionally or inadvertently expressed the relationship between the private and the professional, each expressing different levels of comfort while still emulating ideas from the PST data. Varainja used the tangled balls of twine to hide the shape of the body underneath the cloak. Even while trying to hide our personal selves, the artefacts evidenced revelations in unexpected ways. We discussed the difference between hiding who you are, and enacting a professional identity. Dayna identified a rawness in the PST cloaks exercise, noting that each piece she added to her felted cloak helped cover up the nakedness underneath by being wrapped in a warm, soft, and safe cloak. Pauline's piece predominantly hides the wearer's form, encasing the wearer in a cellophane bubble. This obscuration creates safety as it keeps the individual distanced from her role as a teacher and from the judgment of the students. Pauline's artefact reflects the idea of the PST protected and dependent inside the idealized, iconic apple image of the teacher. Clichés in general have been used as a protective shield or to quell concerns (Lifton, 1989; Arendt, 1978), an explanatory shortcut (dictionary.com, 2016), or even to justify action (Arendt, 1963). The iconic teacher identity has become cliché.

The extent of control we can exercise was a prominent point in our discussion. Debating what we can actually control, what we believe we are controlling, and how this need to control our outward appearance can hamper our development as teachers. For new teachers this distance can create unnecessary issues with feelings of inadequacy and unwillingness to reach out to colleagues for support. In support of the safety of the cliché, the Amway Apple was reportedly very comfortable to 
wear, and without armholes the artwork carries the expectations of being cared for, and feelings of warmth encased in a cocoon, waiting to be birthed.

\section{Moving Forward}

Carl Leggo (2008) recommended "we need to know our stories before we can attend to the stories of others with respect and care" (p. 92). As artist-researchers, this research process has given us a better understanding of not only the constructions of PST identities, but also our own negotiated identities. This paper offers some examples of the rich discussion generated from making artefacts to represent developing teaching philosophies as a method for moving PSTs beyond naïve and clichéd notions of teacher identity. The artefact offers a new lens to discuss and deconstruct inchoate topics with aspiring teachers. With artefacts in hand, the use of the Parallaxic Praxis model, and guided by the Ekphrastic Catechization process, new spaces of investigation into teacher identity formation are possible.

\section{Acknowledgement}

This research is funded by the Social Sciences and Humanities Research Council of Canada.

\section{References}

Antiphon. (2016). In Oxford English Dictionary online. Retrieved from http://www. oed.com/view/Entry/8760?redirected From=antiphon\&

Arendt. H. (1963). Eichmann in Jerusalem: A report on the banality of evil. New York: Viking Press.

Arendt, H. (1978). Life of the mind: Thinking. San Diego, CA: Harcourt Brace Jovanovich.

Bakhtin, M. M. (1981). The dialogic imagination: Four essays. M. Holquist (Trans.). Austin, Texas: University Press.
Barnes, G., Crowe, E., \& Schaefer, B. (2007). The cost of teacher turnover in five school districts: A pilot study. National Council on Teaching and America's Future. Retrieved from http:// nctaf.org/wp-content/uploads/2012/01/ NCTAF-Cost-of-Teacher-Turnover-2007-fullreport.pdf

Barone, T., \& Eisner, E. W. (2012). Arts-based research. Thousand Oaks, CA: Sage. 
Beattie, M. (1997). Fostering reflective practice in teacher education: Inquiry as a framework for the construction of a professional knowledge in teaching. Asia- Pacific Journal of Teacher Education, 25(2), 111-128. doi:10.1080/1359866970250202

Beltman, S., Glass, C., Dinham, J., Chalk, B., \& Nguyen, B. (2015). Drawing identity: Beginning pre-service teachers' professional identities. Issues in Educational Research, 25(3), 225-245.

Boe, E., Cook, L., \& Sunderland, R. (2008). Teacher turnover: Examining exit attrition, teacher area transfer, and school migration. Exceptional Children, 75(1), 7-31.

Boulton-Funke, A. (2014). Narrative form and Yam Lau's Room: The encounter in arts based research. International Journal of Education \& the Arts, 15(17), 1-17.

Buchanan, J. (2015). Metaphors as two-way mirrors: Illuminating pre-service to in-service teacher identity development. Australian Journal of Teacher Education, 40(10), 32-50.

Carlyle, D., \& Woods, P. (2002). Emotions of teacher stress. Stoke on Trent, UK: Trentham Books.

Cheng, M. M. H., Chan, K.W., Tang, Y. F., \& Cheng, A. Y. N. (2009). Pre-service teacher education students' epistemological beliefs and their conceptions of teaching. Teaching and Teacher Education, 25, 319-327.

Clandinin, D. J., Schaefer, L., Long, J. S., Steeves, P., McKenzie-Robblee, S., Pinnegar, E., et al. (2012, April 30). Early career teacher attrition: Problems, possibilities, potentials. Centre for Research for Teacher Education and Development: University of Alberta. Retrieved from http://www.elementaryed. ualberta.ca/en/Centres/CRTED/ /media/ elementaryed/Documents/Centres/CRTED/ ECA__FINAL_Report.pdf

Clark, R., \& Antonelli, F. (2009). Why teachers leave: Results of an Ontario survey 2006-08. Ontario Ministry of Education. Retrieved from http:// www.otffeo.on.ca/english/media_room/ briefs/why_teachers_leave.pdf

Cliché. (2016). In Dictionary.com online. Retrieved from http://dictionary.reference.com/brow se/cliche?s=t
Collins English dictionary (11th ed.). (2011). Glasgow, Scotland: HarperCollins.

Dewey, J. (1934/2005). Art as experience. New York: Perigee.

Eisner, E. (2008). Art and knowledge. In G. Knowles \& A. L. Cole (Eds.), Handbook of the arts in qualitative research (pp. 3-12). Thousand Oaks: Sage.

Eren, A., \& Tekinarslan, E. (2013). Prospective teachers' metaphors: Teacher, teaching, learning, instructional material and evaluation courses. International Journal of Social Sciences and Education, 3(2), 345-445.

Forbes. (2015). Forbe's America's largest private companies. Retrieved from http://www. forbes.com/companies/amway/

Gambhir, M., Broad, K., Evans, M., \& Gaskell, J. (2008, September). Characterizing initial teacher education in Canada: Themes and issues. International Alliance of Leading Education Institutes. University of Toronto. Retrieved from http://www.oise.utoronto. ca/ite/UserFiles/File/CharacterizingITE.pdf

Gay, G., \& Neftali Kirkland, K. (2003). Developing cultural critical consciousness and selfreflection in preservice teacher education. Theory Into Practice, 42(3), 181-187.

Gee, J. P. (2000). Identity as an analytic lens for research in education. Review of Research in Education, 25, 99-125. doi:10.3102/0091732 X025001099

Geijsel, F., \& Meijers, F. (2005). Identity learning: The core process of educational change. Educational Studies, 31(4), 419-430. doi:10.1080/03055690500237488

Haiven, M., \& Khasnabish, A. (2014). The radical imagination. Winnipeg, MB: Fernwood.

Head, F. (1992). Student teaching as initiation into the teaching profession. Anthropology \& Education Quarterly, 23(2), 89-107.

Hess, Ed. (2011, Feb. 24). The business revolution that's destroying the American Dream. Forbes. Retrieved from http://www.forbes. com/2011/02/24/destroy-american-dreamleadership-leaders-financialism.html 
Hong, J. Y. (2010). Pre-service and beginning teachers' professional identity and its relation to dropping out of the profession. Teaching and Teacher Education, 26(8), 1530-1543.

Hooks, B. (2010). Teaching critical thinking: Practical wisdom. New York: Routledge.

Izadinia, M. (2013). A review of research on student teachers' professional identity. British Educational Research Journal, 39(4), 694-713. doi:10.1080/01411926.2012.679614

King, T. (2003). The truth about stories, a Native narrative. Toronto, ON: House of Anansi Press.

Leggo, C. (2008). The ecology of personal and professional experience: A poet's view. In M. Cahnmann-Taylor \& R. Siegesmund (Eds.) Arts-based research in education: Foundations for practice (pp. 89-97). New York: Routledge.

Lifton, R. J. (1989). Thought reform and the psychology of totalism: A study of brainwashing in China. Chapel Hill, NC: UNC Press.

Liu, X., \& Ramsey, J. (2008). Teachers' job satisfaction: Analyses of the teacher follow-up survey in the United States for 2000-01. Teaching and Teacher Education, 24, 1173-1184.

Lotz, C. (2012). Distant presence: Representation, painting and photography in Gerhard Richter's reader. Symposium: Canadian Journal for Continental Philosophy, 1, 87-111.

Maarhuis, P., \& Sameshima, P. (2013, June 5). Pedagogy and parallax: The narrative canvasses of a Clothesline Project. Presentation for the Arts Researchers \& Teachers Society special interest group, Canadian Society for the Study of Education, Victoria, BC.

Maarhuis, P., \& Sameshima, P., \& Chalykoff, J. P. (2014, May 25). Research-antiphona: One transcript, four responses, and five catechizations. Arts, Researchers \& Teachers Society, Canadian Society for the Study of Education, St. Catharines, ON.

Marino, M. T., Sameshima, P., \& Beecher, C. C. (2009). Enhancing TPACK with assistive technology: Promoting inclusive practices in preservice teacher education. Contemporary Issues in Technology and Teacher Education, 9(2).
Morrill, J., \& Stancill, N. (1995, March 20). Yager motivational tapes reel in cash. The Charlotte Observer. Retrieved from http://www.ex-cult. org/Groups/Amway/dexter-yager-2.txt

NCES (National Center for Education Statistics). (2011, September). Beginning teacher attrition and mobility: Results from the first through third waves of the 20007-08 beginning teacher longitudinal study. Retrieved from http:// nces.ed.gov/pubs2011/2011318/

Neumiller, J., Corbett, C., Gates, B., \& Vandermause, R. (2015). Preserving self: Empowering older persons with multiple chronic medical conditions. Patient Centered Outcomes Research Institute. Washington State University. Retrieved from https://nursing.wsu.edu/research/fundedprojects/preserving-self-empoweringolder-persons-with-multiple-chronicmedical-conditions/

Northcote, M., \& Featherstone, T. (2006). New metaphors for teaching and learning in a university context. In Critical visions: Proceedings of the 29th Annual HERDSA Conference, Perth, WA, 10-12 July (pp. 251-258). Retrieved from http://research. avondale.edu.au/cgi/viewcontent. cgi?article $=1018 \&$ context=edu_conferences

Pope, D., Brown, M., \& Miles, S. (2015). Overloaded and underprepared: Strategies for stronger schools and healthy, successful kids. San Francisco: Jossey-Bass.

Pinnegar, S., Mangelson, J., Reed, M., \& Groves, S. (2011). Exploring preservice teachers' metaphor plotlines. Teaching and Teacher Education, 27, 639-647. doi:10.1016/j. tate.2010.11.002

Sameshima, P. (2007a). Seeing Red - A pedagogy of parallax: An epistolary bildungsroman on artful scholarly inquiry. Amherst, NY: Cambria Press.

Sameshima, P. (2007b). Seeing shadows in new light: A procatalepsis on narrative inquiry as professional development. (Special issue: Creativity and education: An international perspective), New Horizons in Education, 55(3), 10-21. 
Sameshima, P. (2009). Stop teaching! Hosting an ethical responsibility through a pedagogy of parallax. Journal of Curriculum and Pedagogy, 6(1), 11-18. doi:10.1080/15505170.2009.10411 719

Sameshima, P., \& Vandermause, R. (2008). Parallaxic praxis: An artful interdisciplinary collaborative research methodology. In B. Kožuh, R. Kahn, \& A Kozlowska (Eds.), The practical science of society (pp. 141-152). Grand Forks, Nottingham, Krakow: The College of Education and Human Development \& Slovenian Research Agency (AARS).

Sameshima, P., Vandermause, R., Chalmers, S., \& Gabriel (2009). Climbing the ladder with Gabriel: Poetic inquiry of a methamphetamine addict in recovery. Boston: Sense.

Saunders, V. (2015) ". . .": Using a non-bracketed narrative to story recovery in Aboriginal mental health care. Unpublished thesis. Nursing, Midwifery \& Nutrition, College of Healthcare Sciences, Division of Tropical Health and Medicine, James Cook University. Townsville, Australia.

Schafer, L. (2013). Beginning teacher attrition: A question of identity making and identity shifting. Teachers and Teaching: Theory and Practice. 19(3), 260-274.
Sinner, A., Wicks, J., \& Rak, S. (2015). Minding the gap: Exploring the potential of the teaching portfolios as curricular innovation. Visual Arts Research, 41(1), 16-26. doi:10.5406/ visuartsrese.41.1.0016

Spivak, G. (2013). An aesthetic education in the era of globalization. Cambridge, MA: Harvard University Press.

Sullivan, G. (2005). Art practice as research: Inquiry in the visual arts. Thousand Oaks, CA: Sage.

The Guardian Teacher Network. (2015, October 11). 'Show us that you care': A student's view on what makes a perfect teacher. Retrieved from http://www.theguardian.com/teachernetwork/2015/oct/11/show-care-studentsview-what-makes-perfect-teacher

Thomas, L., \& Beauchamp, C. (2011). Understanding new teachers' professional identities through metaphor. Teaching and Teacher Education, 27, 762-769. doi:10.1016/j. tate.2010.12.007

Weber, S. J., \& Mitchell, C. (1996). Drawing ourselves into teaching: Studying the images that shape and distort teacher education. Teaching \& Teacher Education, 12(3), 303-313.

White, B. E., \& Lemieux, A. (2015, Autumn). Reflecting selves: Pre-service teacher identity development explored through material culture. LEARNing Landscapes 9(1), 267-283. 


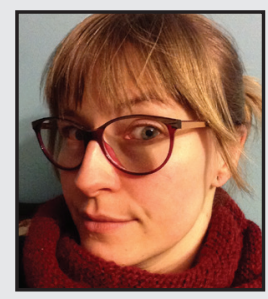

R. Varainja Stock is a PhD Candidate in Educational Studies at Lakehead University in Thunder Bay. Her studies focus on the role of arts in society and the possibilities that arts-integrated research open up for inquiry and how we understand knowledge. Varainja likes to build costumes and props from found materials, pushing her to work within the materials available.

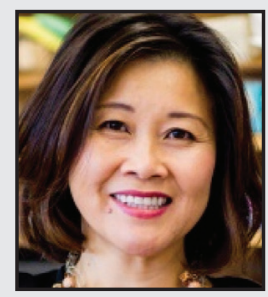

Pauline Sameshima is a Canada Research Chair in Arts Integrated Studies at Lakehead University in Thunder Bay, Ontario, Canada. Her work centers on expanding notions of holistic learning, researching, and living. Specifically, Pauline's interdisciplinary projects integrate multi-modal translations of data to catalyze creative innovation, generate novel understandings, and provoke new dialogues.

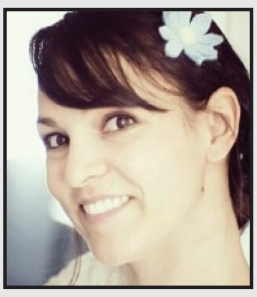

Dayna Slingerland is a graduate from the Masters of Education program at Lakehead University. Her artistic experience includes creating art using natural, locally sourced materials, as well as engaging with textiles. Currently working in the realms of teacher, artist and researcher she honors the importance of play, process, and community within her artistic practice. 